\title{
Determination of dibenzo-p-dioxins, dibenzofurans and dioxin-like PCBs in fish and meat in Lithuania
}

\author{
Rasa Mašaraite் $\dot{1}^{1,3 *}$, \\ Julijonas Petraitis ${ }^{1}$, \\ Inga Jarmalaité ${ }^{1}$, \\ Evaldas Naujalis ${ }^{3}$ \\ ${ }^{1}$ National Food and Veterinary \\ Risk Assessment Institute, \\ J. Kairiūkššcio str. 10, \\ LT-08409 Vilnius, Lithuania \\ ${ }^{2}$ Natural Science and \\ Technology Center, \\ Chemistry Institute, \\ A. Goštauto str. 9, \\ LT-01108 Vilnius, Lithuania \\ ${ }^{3}$ Natural Science and \\ Technology Center, \\ Semiconductor Physics Institute, \\ A. Goštauto str. 11, \\ LT-01108 Vilnius, Lithuania
}

\begin{abstract}
The method, validated for determination of dibenzo-p-dioxins, dibenzofurans and dioxin like-polychlorinated biphenyls, was carried out in fish and meat matrixes. Validation criteria on repeatability and reproducibility conditions complies with the requirements of the European Comission. Validated methods were successfully applied for determination of PCDD / F and DL-PCB in fish of the Baltic sea and meat. Concentrations of PCDD / F and DL-PCB were analysed in Baltic herring, salmon, sprats and cod liver. Exceedings of the maximum limit were determined in 9 of 25 Baltic herring, 2 of 9 salmon, 1 of 33 sprats and 9 of 10 Baltic cod liver samples. Concentrations in others fish and meat matrixes were in a "normal" level.
\end{abstract}

Key words: PCDD, PCDF, DL-PCB, Baltic Sea, herring, sprat, validation

\section{INTRODUCTION}

Polychlorinated dibenzo-p-dioxins (PCDD), polychlorinated dibenzofurans (PCDF) and dioxin like polychlorinated biphenyls are a group of toxic and persistent organic pollutants, whose effect on human health and on the environment include dermal toxicity, immunotoxicity, reproductive effects and teratogenicity, endocrine disrupting effects and carcinogenicity. The term "dioxin" refers to 75 congeners of PCDD and 135 congeners of PCDF. Among these, 210 congeners, 17 congeners can have chlorine atoms at least in the

\footnotetext{
*Corresponding author. E-mail: rmasaraite@vet.lt
}

positions 2, 3, 7 and 8 of the parent molecule. Polychlorinated biphenyls (PCB) are structurally somewhat similar to the dioxins. There are $209 \mathrm{PCB}$ congeners divided into 2 main groups: (1) the "dioxin-like PCBs", a group of 12 PCBs showing similar toxicological properties to the dioxins, and (2) the non-dioxin-like PCBs, which are of lower toxicity, and normally the predominant ones in the enviromental samples [1-3].

Fish, meat and their products play a significant role in the dietary intake of PCDD / PCDF, therefore, the analytical methods of dibenzo-p-dioxins, dibenzofurans and PCB's have been developed by the HR-GC / MS. Despite very small amounts of these congeners, their toxicity is very high; thus, 
sensitivity and selectivity of analytical methods are very important analysing samples with the HR-GC/MS, as it is possible to achieve concentrations in the level of $\mathrm{g}^{-9}$ (ng) or even $\mathrm{g}^{-12}(\mathrm{pg})$.

The aim of this study was to validate analytical methods and the concentrations of three groups of analytes PCDD, PCDF and dioxin-like PCBs in fish and meat in Lithuania (in 2005-2010), because more than $90 \%$ of the average human intake of polychlorinated-p-dioxins, polychlorinated dibenzofurans and polychlorinated biphenyls originates from food, especially that of animal origin [8-11].

\section{MATERIALS AND METHODS}

\section{Instrumentation}

Analysis of polychlorinated organic pollutants was performed with a high resolution mass spectrometer AutoSpec Premier (Waters Corporation, USA) coupled with an Agilent GC 6890N (Agilent technologies, USA).

\section{HRGCMS conditions}

Chromatographic separation was achieved by splitless injection (CTC analytics PAL system) of $3 \mu \mathrm{l}$ for PCDD / F and $2 \mu \mathrm{l}$ for DL - PCB on a column with a length of $60 \mathrm{~m}$, ID $0.25 \mathrm{~mm}, \mathrm{ft} 0.1 \mu \mathrm{m}$. The GC oven for PCDD / PCDF analysis was programmed as follows:
$1.120^{\circ} \mathrm{C}(2 \mathrm{~min})$
$2.25^{\circ} \mathrm{C} / \mathrm{min}-250^{\circ} \mathrm{C}$
3. $2.5^{\circ} \mathrm{C} / \mathrm{min}-285^{\circ} \mathrm{C}$
$4.10^{\circ} \mathrm{min}-340^{\circ} \mathrm{C}(4 \mathrm{~min})$;
And for DL - PCB:
$1.120^{\circ} \mathrm{C}(2 \mathrm{~min})$
$2.30^{\circ} \mathrm{C} / \mathrm{min}-200^{\circ} \mathrm{C}$
$3.6^{\circ} \mathrm{C} / \mathrm{min}-280^{\circ} \mathrm{C}$
$4.10^{\circ} \mathrm{C} / \mathrm{min}-320^{\circ} \mathrm{C}(5 \mathrm{~min})$.

The MS was operated in SIM mode at a resolution of 10.000 , and the two most intense ions of the molecular ion clusters were monitored for the unlabelled and labelled isomers. Specific quantitation ions are presented in Table 1.

Calibration was done by Isotope dilution, when the labelled compounds are added to samples prior to extraction. Quantitation limits for target compounds are: $0.01 / 0.05 / 0.1-4 / 20 / 40 \mathrm{ng} / \mathrm{ml}$ for TCDD, TCDF / PeCDD, PeCDF, HxCDD, HxCDF, HpCDD, HpCDF / OCDD, OCDF and $0.1-100 \mathrm{ng} / \mathrm{ml} \mathrm{DL} \mathrm{-} \mathrm{PCB.} \mathrm{A} \mathrm{calibration} \mathrm{curve,} \mathrm{encom-}$ passing the concentration range, is prepared for the each compound to be determined. If the relative response for any compound is constant (less than 15\% coefficient of variation) over the calibration range, the RRF may be used for that compound.

\section{Chemicals}

All solvents used as well as the silica, florisil, carbon were of trace analysis quality. The $\mathrm{C}_{18}$-modified silica, anhydrous sodium sulphate, sodium hydroxide, sulphuric acid (9597\%) were purchased from Riedel-de Haën (Germany), florisil (0.150-0.250 mm) - from MERCK (Germany). Carboblack C 80 / 100 and carbovlack B 60 / 80 were purchased from RESTEC CORPORATION (USA). All adsorbents were heated at the temperature of $550{ }^{\circ} \mathrm{C}$ prior to analysis and deactivated with corresponding content of water.

${ }^{12} \mathrm{C}_{12}$ and ${ }^{13} \mathrm{C}_{12}$ stock solutions were from LGC Promochem (Wesel, Germany).

\section{Sample preparation}

Hot smoked sprats were taken for method validation in fish matrix. The true value was approved by the certified reference laboratory. Pork meat for the proficiency test was chosen for validation in meat matrix. The assumed value was taken as a target concentration.

Table 1. Ions specified for selected ion monitoring for PCDD / PCDF and DL - PCB

\begin{tabular}{|c|c|c|c|c|c|}
\hline${ }^{12} C_{12}$ analyte & \multicolumn{2}{|c|}{ Mass (m/z) } & ${ }^{13} C_{12}$ analyte & \multicolumn{2}{|c|}{ Mass (m/z) } \\
\hline${ }^{12} \mathrm{C}_{12}-\mathrm{TCDF}$ & 303.9016 & 305.8987 & ${ }^{13} \mathrm{C}_{12}-\mathrm{TCDF}$ & 315.9419 & 317.9389 \\
\hline${ }^{12} \mathrm{C}_{12}-\mathrm{TCDD}$ & 319.8965 & 321.8936 & ${ }^{13} \mathrm{C}_{12}-\mathrm{TCDD}$ & 331.9368 & 333.9339 \\
\hline${ }^{12} C_{12}-$ PeCDF & 339.8597 & 341.8586 & ${ }^{13} C_{12}-$ PeCDF & 351.9000 & 353.8970 \\
\hline${ }^{12} C_{12}-\mathrm{PeCDD}$ & 353.8576 & 355.8546 & ${ }^{13} C_{12}-\mathrm{PeCDD}$ & 365.8978 & 367.8949 \\
\hline${ }^{12} \mathrm{C}_{12}-\mathrm{HxCDF}$ & 373.8207 & 375.8178 & ${ }^{13} \mathrm{C}_{12}-\mathrm{HxCDF}$ & 385.8610 & 387.8580 \\
\hline${ }^{12} \mathrm{C}_{12}-\mathrm{HxCDD}$ & 389.8156 & 391.8127 & ${ }^{13} C_{12}-H x C D D$ & 401.8559 & 403.8530 \\
\hline${ }^{12} \mathrm{C}_{12}-\mathrm{HpCDF}$ & 407.7818 & 409.7788 & ${ }^{13} \mathrm{C}_{12}-\mathrm{HpCDF}$ & 419.8220 & 421.8191 \\
\hline${ }^{12} \mathrm{C}_{12}-\mathrm{HpCDD}$ & 423.7767 & 425.7737 & ${ }^{13} \mathrm{C}_{12}-\mathrm{HpCDD}$ & 435.8169 & 437.8140 \\
\hline${ }^{12} C_{12}-$ OCDF & 441.7428 & 443.7398 & ${ }^{13} \mathrm{C}_{12}-\mathrm{OCDF}$ & 453.7830 & 455.7801 \\
\hline${ }^{12} C_{12}-O C D D$ & 459.7348 & 461.7320 & ${ }^{13} C_{12}-O C D D$ & 471.7750 & 473.7721 \\
\hline${ }^{12} \mathrm{C}_{12}-\mathrm{TCB}$ & 289.9223 & 291.9194 & ${ }^{13} \mathrm{C}_{12}-\mathrm{TCB}$ & 301.9626 & 303.9597 \\
\hline${ }^{12} C_{12}-\mathrm{PeCB}$ & 325.8804 & 327.8775 & ${ }^{13} C_{12}-\mathrm{PeCB}$ & 337.9206 & 339.9178 \\
\hline${ }^{12} \mathrm{C}_{12}-\mathrm{H} \times \mathrm{CB}$ & 359.8415 & 361.8385 & ${ }^{13} \mathrm{C}_{12}-\mathrm{HxCB}$ & 371.8817 & 373.8788 \\
\hline${ }^{12} \mathrm{C}_{12}-\mathrm{HpCB}$ & 393.8025 & 395.7995 & ${ }^{13} \mathrm{C}_{12}-\mathrm{HpCB}$ & 405.8428 & 407.8398 \\
\hline
\end{tabular}


Sprat and meat samples were finely grounded (fish - in whole weight) and homogenised prior to analysis. About $10 \mathrm{~g}$ of fish ${ }^{1}$ and about $20 \mathrm{~g}$ of meat ${ }^{1}$ were dried with $50 \mathrm{~g}$ of anhydrous sodium sulphate and spiked with ${ }^{13} \mathrm{C}_{12}$ - labelled standards. Fat content was measured gravimetricaly.

Fish and meat samples, analysed in 2005-2010 in Lithuania, were taken for statistical analysis [4-7].

\section{Clean-up}

For the analysis of PCDD / PCDF and DL-PCB the cleanup procedure, applied to the extracts, is shown in Fig. 1. Fraction A contains analytes of mono - ortho $\mathrm{PCB}$, fraction $\mathrm{B}$ - non-ortho PCB and fraction C - PCDD / PCDF. At every cleaning step, the extracts were evaporated to approximately $1 \mathrm{ml}$, before starting the other step. The final volume of the extract was replaced to an insert of the vial, evaporated by a gentle stream of nitrogen and diluted to $10 \mu \mathrm{l}$ for PCDD / F and $100 \mu \mathrm{l}$ for DL - PCB with recovery standards [4-7].

\section{RESULTS AND DISCUSSION}

Validation of PCDD / F and DL - PCB in meat and fish was done. Hot smoked sprats and pork meat were chosen as target matrixes, as well as their target concentrations were confirmed by the reference laboratories. The level of interest was the LOQ level for fish WHO-TEQ ${ }_{(1998)}$ PCDD / F 4 ng/kg, WHO-TEQ ${ }_{(1998)}$-PCDD / F-PCB 8 ng/kg fresh weight. Also, WHO-TEQ ${ }_{(1998)}-\mathrm{PCDD} / \mathrm{F} 1 \mathrm{ng} / \mathrm{kg}$ and $\mathrm{WHO}^{-T_{E}} \mathrm{(1998)}-\mathrm{PCDD} / \mathrm{F}-\mathrm{PCB} 1.5 \mathrm{ng} / \mathrm{kg}$ fat for meat matrix (pork meat).

Method precision, trueness, limits of quantification, recoveries were verified on repeatability and reproducibility conditions (Tables 2 and 3). Validation was carried out according to the requirements of the Commission Regulation (EC).

Limits of quantification for WHO-TEQ ${ }_{(1998)}-\mathrm{PCDD} / \mathrm{F}$ and WHO-TEQ ${ }_{(1998)}-\mathrm{PCDD} / \mathrm{F}-\mathrm{PCB}$ are less than $1 / 5$ of the

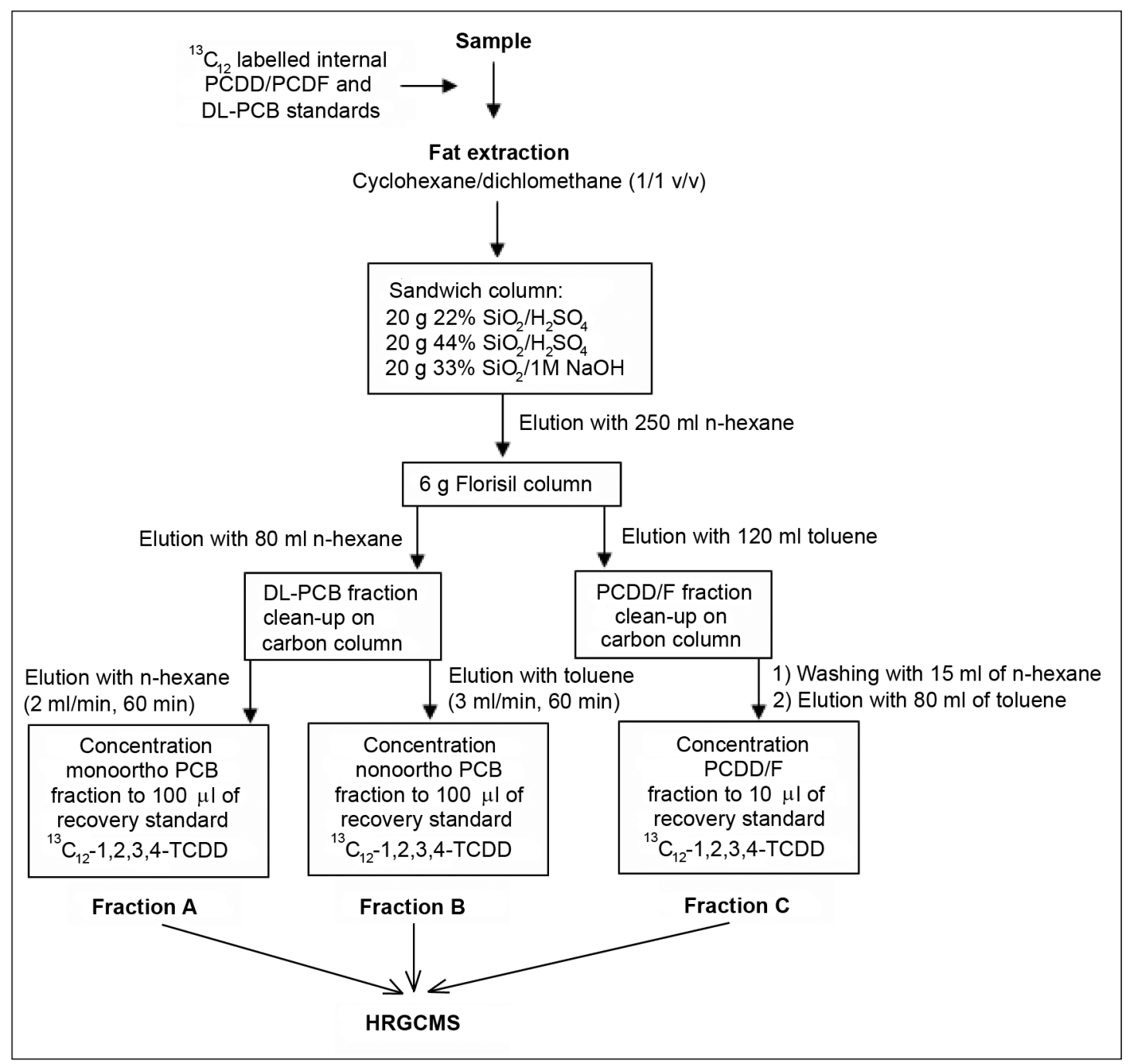

Fig. 1. The clean-up procedure

Size of the sample depends on the expected amount of fat content. Approximately $3 \mathrm{~g}$ of fat is taken for further analysis 
Table 2. Validation data in fish matrix

\begin{tabular}{|c|c|c|c|c|c|c|c|c|}
\hline & $\begin{array}{c}\text { Average conc. on repe- } \\
\text { atability conditions, } \\
n \mathrm{ng} / \mathrm{kg}(\mathrm{n}=5)\end{array}$ & $\begin{array}{l}\text { Average conc. on } \\
\text { reproducibility condi- } \\
\text { tions, } n g / k g ~ n=10)\end{array}$ & $\begin{array}{l}\mathrm{SD}_{\mathrm{r}} \\
\mathrm{ng} / \mathrm{kg}\end{array}$ & $\begin{array}{c}\mathrm{SD}_{\mathrm{R}^{\prime}} \\
\mathrm{ng} / \mathrm{kg}\end{array}$ & $\begin{array}{l}\text { RSD, } \\
\%\end{array}$ & $\begin{array}{l}\mathrm{RSD}_{\mathrm{R}^{\prime}} \\
\%\end{array}$ & $\begin{array}{l}\text { Trueness on } \\
\text { repeatability } \\
\text { conditions, } \%\end{array}$ & $\begin{array}{l}\text { Trueness on } \\
\text { reproducibility } \\
\text { conditions, \% }\end{array}$ \\
\hline $\begin{array}{l}\text { Lower bound } \\
\text { (PCDD / PCDF) }\end{array}$ & 2.99 & 3.17 & 0.07 & 0.39 & 2.22 & 12.45 & -11.92 & -6.67 \\
\hline $\begin{array}{l}\text { Upper bound } \\
\text { (PCDD / PCDF) }\end{array}$ & 3.00 & 3.18 & 0.07 & 0.41 & 2.22 & 12.81 & -11.87 & -6.49 \\
\hline $\begin{array}{c}\text { Lower bound } \\
\text { (PCDD / PCDF, PCB) }\end{array}$ & 6.67 & 7.10 & 0.12 & 0.51 & 1.85 & 7.24 & -17.53 & -12.26 \\
\hline $\begin{array}{c}\text { Upper bound } \\
\text { (PCDD / PCDF, PCB) }\end{array}$ & 6.67 & 7.10 & 0.12 & 0.52 & 1.85 & 7.38 & -17.51 & -12.19 \\
\hline
\end{tabular}

Table 3. Validation data in meat matrix

\begin{tabular}{|c|c|c|c|c|c|c|c|c|}
\hline & $\begin{array}{l}\text { Average conc. on } \\
\text { repeatability conditi- } \\
\text { ons, } \mathrm{ng} / \mathrm{kg}(\mathrm{n}=5)\end{array}$ & $\begin{array}{l}\text { Average conc. on } \\
\text { reproducibility condi- } \\
\text { tions, } \mathrm{ng} / \mathrm{kg}(\mathrm{n}=\mathbf{8})\end{array}$ & $\begin{array}{c}\mathrm{SD}_{\mathbf{r}^{\prime}} \\
\mathrm{ng} / \mathrm{kg}\end{array}$ & $\begin{array}{c}S D_{R^{\prime}} \\
n g / k g\end{array}$ & $\begin{array}{c}\text { RSD } \\
\%\end{array}$ & $\begin{array}{c}\mathrm{RSD}_{\mathrm{R}^{\prime}} \\
\%\end{array}$ & $\begin{array}{l}\text { Trueness on } \\
\text { repeatability } \\
\text { conditions, } \%\end{array}$ & $\begin{array}{c}\text { Trueness on } \\
\text { reproducibility } \\
\text { conditions, } \%\end{array}$ \\
\hline $\begin{array}{l}\text { Lower bound } \\
\text { (PCDD / PCDF) }\end{array}$ & 0.722 & 0.69 & 0.09 & 0.03 & 12.4 & 4.49 & 1.6 & -2.3 \\
\hline $\begin{array}{l}\text { Upper bound } \\
\text { (PCDD / PCDF) }\end{array}$ & 0.795 & 0.77 & 0.07 & 0.04 & 8.99 & 5.31 & 4.6 & 1.5 \\
\hline $\begin{array}{c}\text { Lower bound } \\
\text { (PCDD / PCDF, PCB) }\end{array}$ & 3.28 & 3.37 & 0.18 & 0.3 & 0.18 & 8.75 & -5.3 & 0.73 \\
\hline $\begin{array}{c}\text { Upper bound } \\
\text { (PCDD / PCDF, PCB) }\end{array}$ & 3.172 & 3.46 & 0.17 & 0.27 & 0.17 & 7.90 & -4.1 & 1.25 \\
\hline
\end{tabular}

maximum level. Recoveries are in the range of $40-130 \%$ for fish and 60-120\% for meat. HRGCMS chromatograms are shown in Figs. 2, 3, 4, 5.

Determination of dioxins and PCB was carried out in 2005-2010. There were analysed 87 fish samples from the
Baltic sea (Baltic herring, sprat, salmon, cod liver, carp and their products) and 24 animal fat samples (chicken fat, bovine fat, pork fat) (Fig. 6). Most of fish samples were caught in the fisheries ICES $2640 \mathrm{HO}$ or $39 \mathrm{HO}$ of the Baltic sea (Fig. 7).

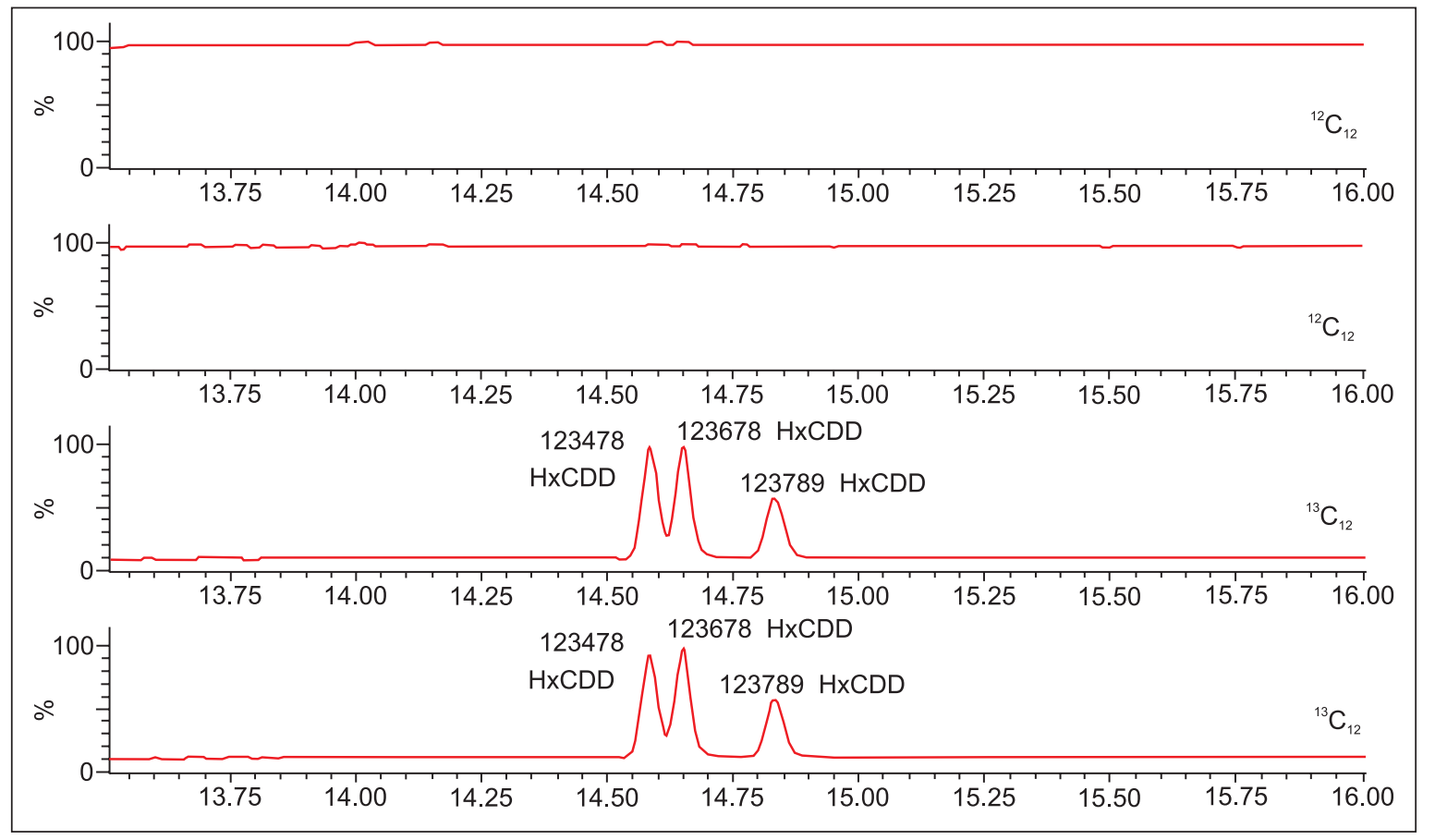

Fig. 2. HR-GCMS chromatogram of fish sample: chromatography column DB $-5 M S, 60 \mathrm{~m} \times 0.25 \mathrm{~mm} \times 0.10 \mu \mathrm{m}$, temperature gradient $120^{\circ} \mathrm{C}(2 \mathrm{~min}), 25^{\circ} \mathrm{C} / \mathrm{min}-250^{\circ} \mathrm{C}, 2.5^{\circ} \mathrm{C} / \mathrm{min}-285^{\circ} \mathrm{C}, 10 \mathrm{C} / \mathrm{min}-340^{\circ} \mathrm{C}(4 \mathrm{~min})$ 


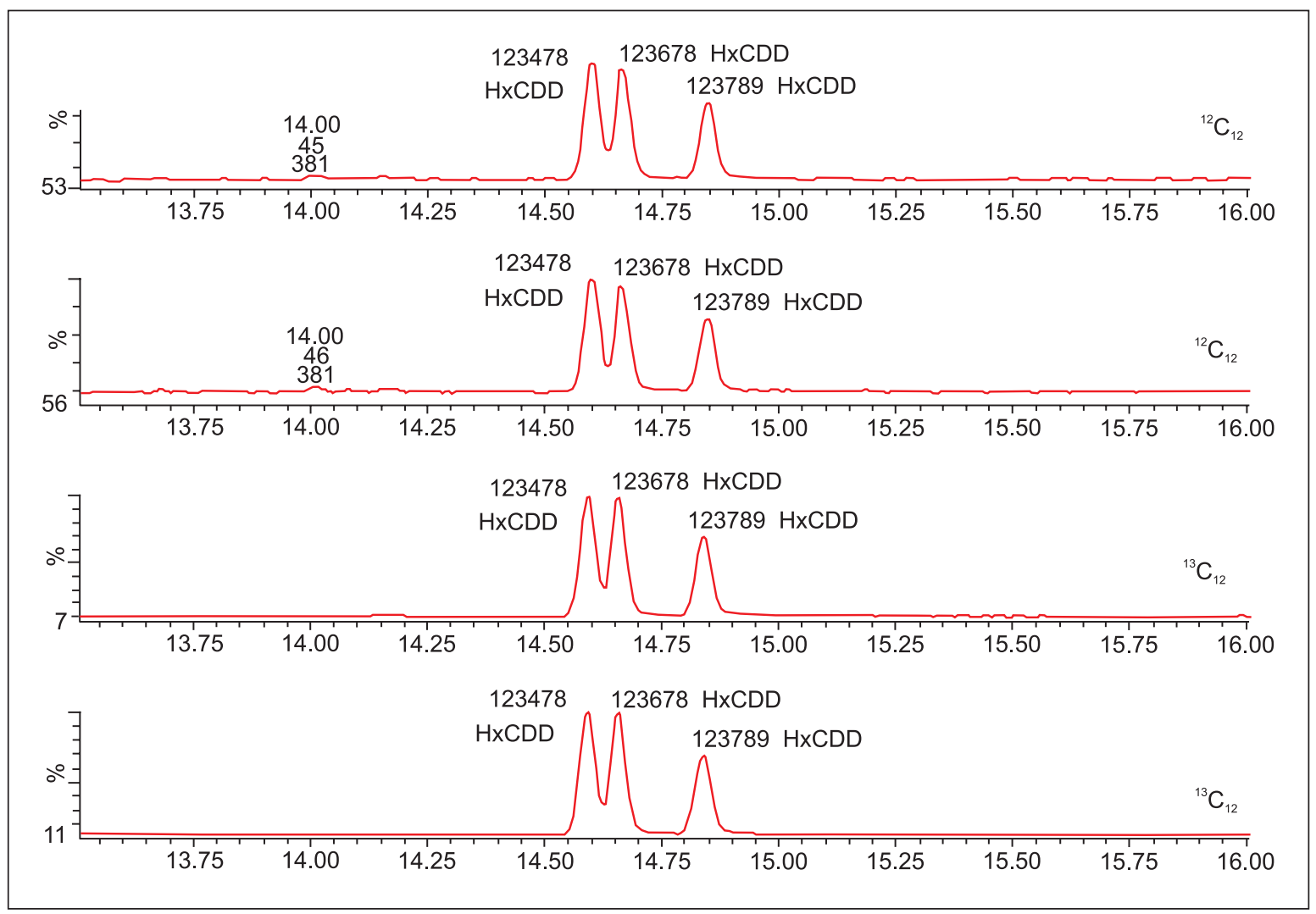

Fig. 3. HR-GCMS chromatogram of fish sample (shown in Fig. 2.) spiked with $0.25 \mathrm{ng} / \mathrm{kg} \mathrm{HxCDD}$ : chromatography column DB - 5MS, $60 \mathrm{~m} \times 0.25 \mathrm{~mm} \times 0.10 \mu \mathrm{m}$, temperature gradient $120^{\circ} \mathrm{C}(2 \mathrm{~min}), 25^{\circ} \mathrm{C} / \mathrm{min}-250^{\circ} \mathrm{C}, 2.5^{\circ} \mathrm{C} / \mathrm{min}-285^{\circ} \mathrm{C}, 10 \mathrm{C} / \mathrm{min}-340^{\circ} \mathrm{C}(4 \mathrm{~min})$

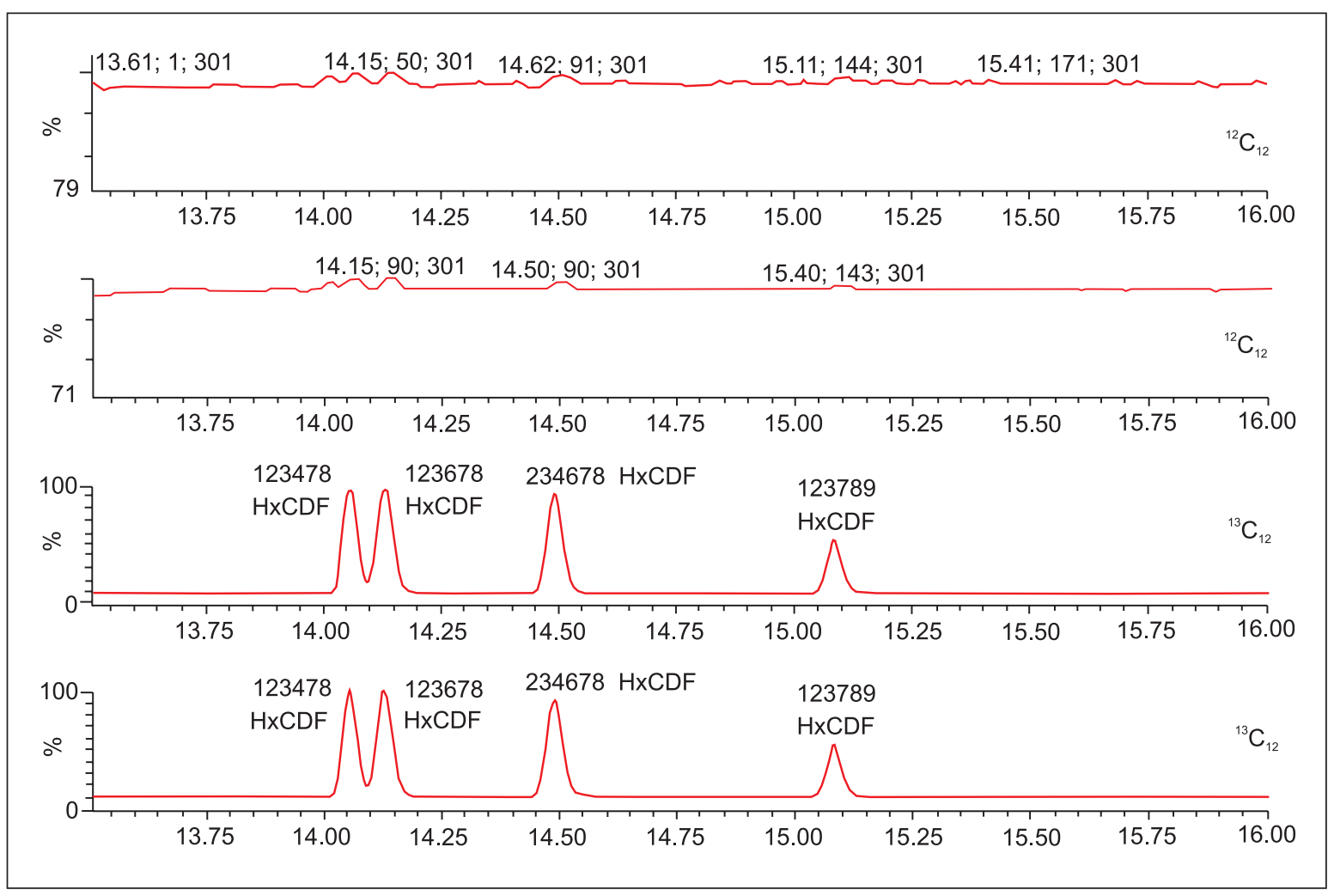

Fig. 4. HR-GCMS chromatogram of fish sample: chromatography column DB $-5 \mathrm{MS}, 60 \mathrm{~m} \times 0.25 \mathrm{~mm} \times 0.10 \mu \mathrm{m}$, temperature gradient $120^{\circ} \mathrm{C}(2 \mathrm{~min}), 25^{\circ} \mathrm{C} / \mathrm{min}-250^{\circ} \mathrm{C}, 2.5^{\circ} \mathrm{C} / \mathrm{min}-285^{\circ} \mathrm{C}, 10^{\circ} \mathrm{C} / \mathrm{min}-340^{\circ} \mathrm{C}(4 \mathrm{~min})$ 


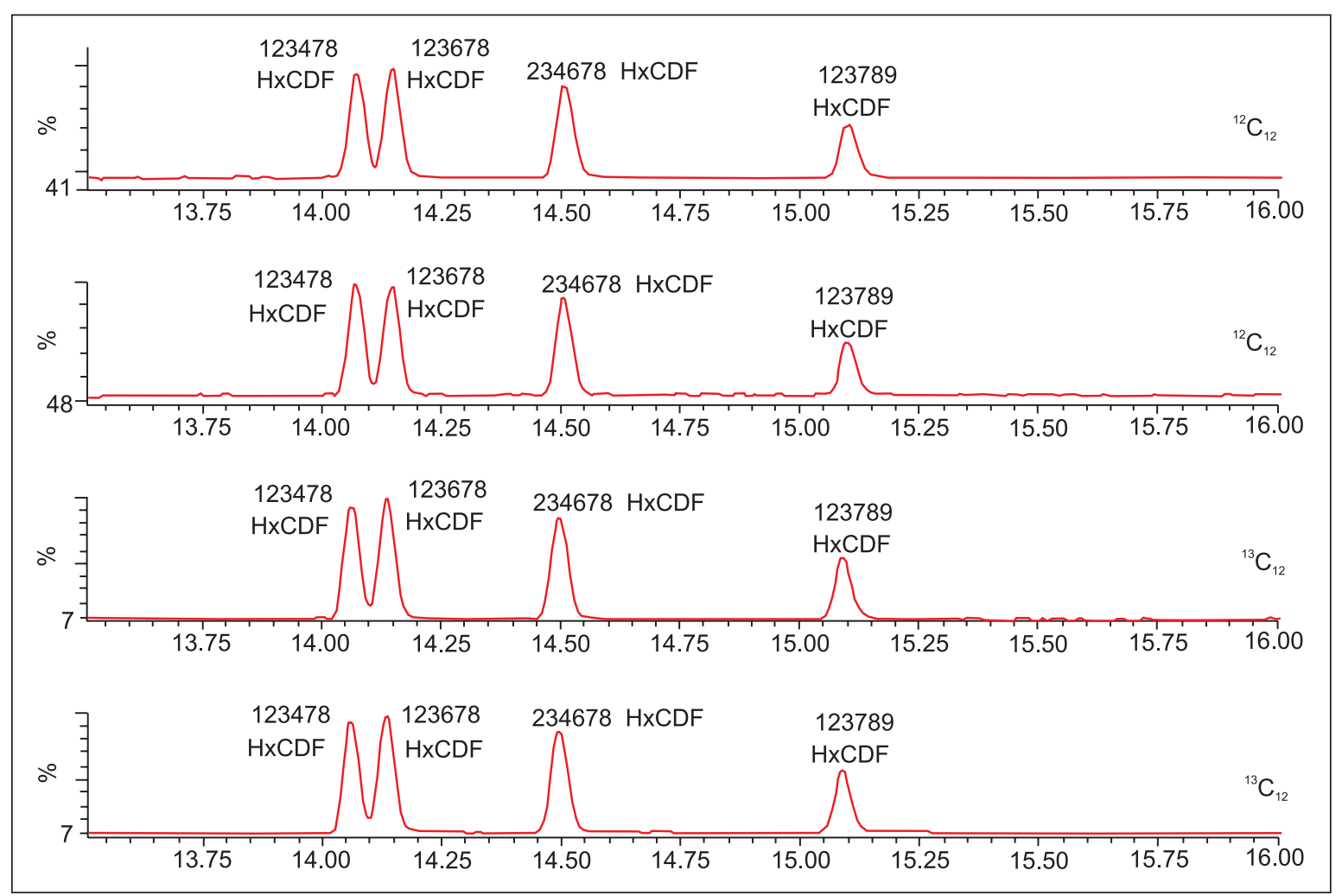

Fig. 5. HR-GCMS chromatogram of fish sample (shown in Fig. 4.) spiked with $0.25 \mathrm{ng} / \mathrm{kg} \mathrm{HxCDF}$ : chromatography column DB - 5MS, $60 \mathrm{~m} \times 0.25 \mathrm{~mm} \times 0.10 \mu \mathrm{m}$, temperature gradient $120^{\circ} \mathrm{C}(2 \mathrm{~min}), 25^{\circ} \mathrm{C} / \mathrm{min}-250^{\circ} \mathrm{C}, 2.5^{\circ} \mathrm{C} / \mathrm{min}-285^{\circ} \mathrm{C}, 10^{\circ} \mathrm{C} / \mathrm{min}-340^{\circ}(4 \mathrm{~min})$

Fig. 6. Samples analysed in 2005-2010

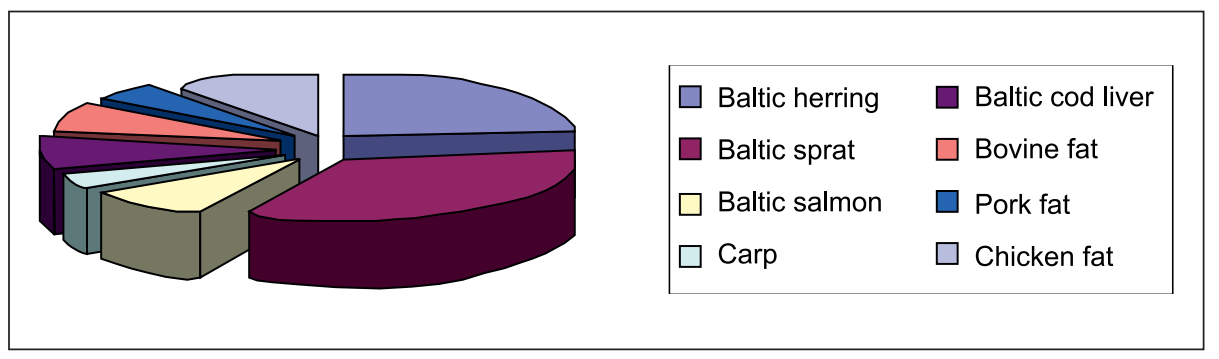

Fig. 7. Fisheries in the Baltic sea by ICES

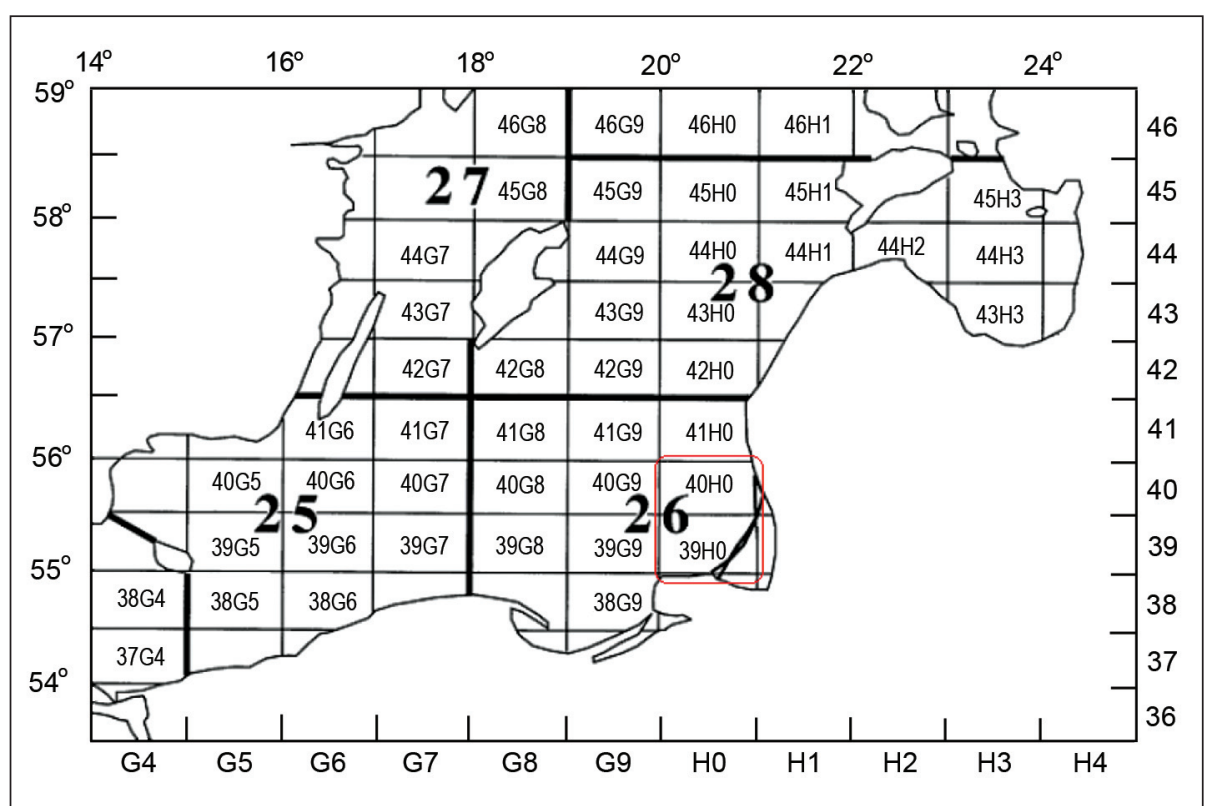


In Figs. 8 and 9, it is seen that concentration of PCDD / F and DL - PCB in Baltic herring and sprats is more or less about the maximum level $\mathrm{WHO}^{-\mathrm{TEQ}_{(1998)}}-\mathrm{PCDD} / \mathrm{F}$ $4 \mathrm{ng} / \mathrm{kg}$ fresh weight and WHO-TEQ ${ }_{(1998)}-\mathrm{PCDD} / \mathrm{F}-\mathrm{PCB}$ $8 \mathrm{ng} / \mathrm{kg}$ fresh weight according to the requirements of the Commission Regulation (EC) and it does not change during the year. $16 \%$ of Baltic herring was found to exceed the maximum limit of WHO-TEQ ${ }_{(1998)}-\mathrm{PCDD} / \mathrm{F}$ (above the blue line in Fig. 8), 36\% of WHO-TEQ ${ }_{(1998)}-\mathrm{PCDD} / \mathrm{F}-\mathrm{PCB}$ (above the red line in Fig. 8).

Only $3 \%$ of Baltic sprats were found to exceed the maximum limit of WHO-TEQ ${ }_{(1998)}-\mathrm{PCDD} / \mathrm{F}-\mathrm{PCB}$ (above the red line in Fig. 9) and none of WHO-TEQ ${ }_{(1998)}-$ PCDD / F (below the blue line in Fig. 9).

Baltic salmon samples, analysed in 2005-2010, are shown in Fig. 10 and cod liver samples - Fig. 11. 22\% of salmon samples were found to exceed the maximum limit of $\mathrm{WHO}^{-T_{E Q}}{ }_{(1998)}-\mathrm{PCDD} / \mathrm{F}-\mathrm{PCB}$ (above the red line in Fig. 10) and none of WHO-TEQ ${ }_{(1998)}-\mathrm{PCDD} / \mathrm{F}$ (below the blue line in Fig. 10).

From Fig. 11 it is noticed that DL - PCB accumulate more than PCDD / F in liver. Only 10\% of samples were not exceeding the maximum limit for WHO-TEQ ${ }_{(1998)}-\mathrm{PCDD} / \mathrm{F}$ (below the blue line in Fig. 11) and 90\% of cod liver was exceeding WHO-TEQ ${ }_{(1998)}-\mathrm{PCDD} / \mathrm{F}-\mathrm{PCB}$ (above the red line in Fig. 11).

Meat contamination was found to be insignificant and the concentrations did not exceed the maximum limits neither for WHO-TEQ ${ }_{(1998)}-\mathrm{PCDD} / \mathrm{F}$ nor for WHO-TEQ ${ }_{(1998)}$ PCDD / F-PCB.

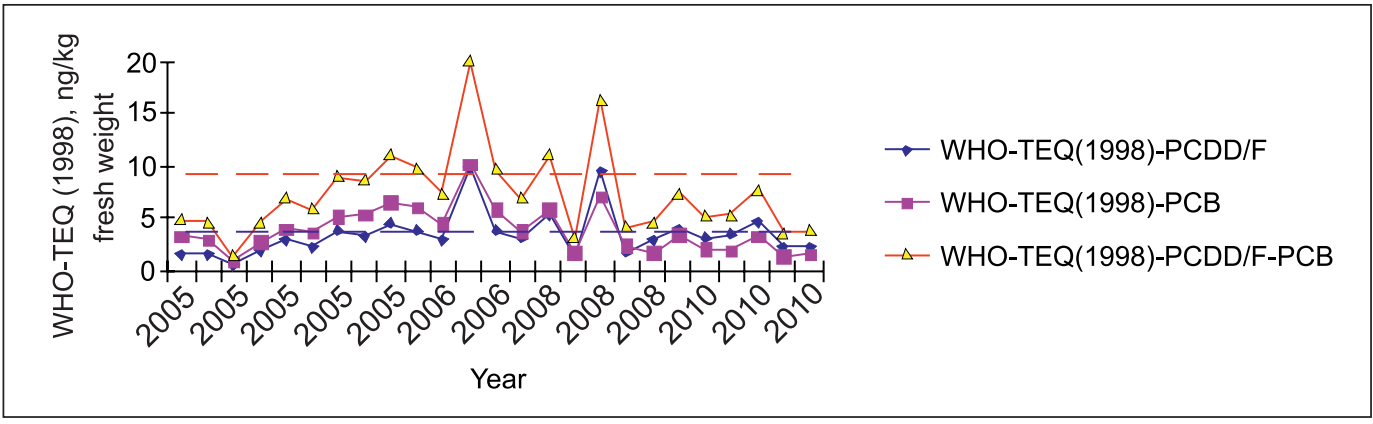

Fig. 8. Baltic herring analysed in 2005-2010 in Lithuania

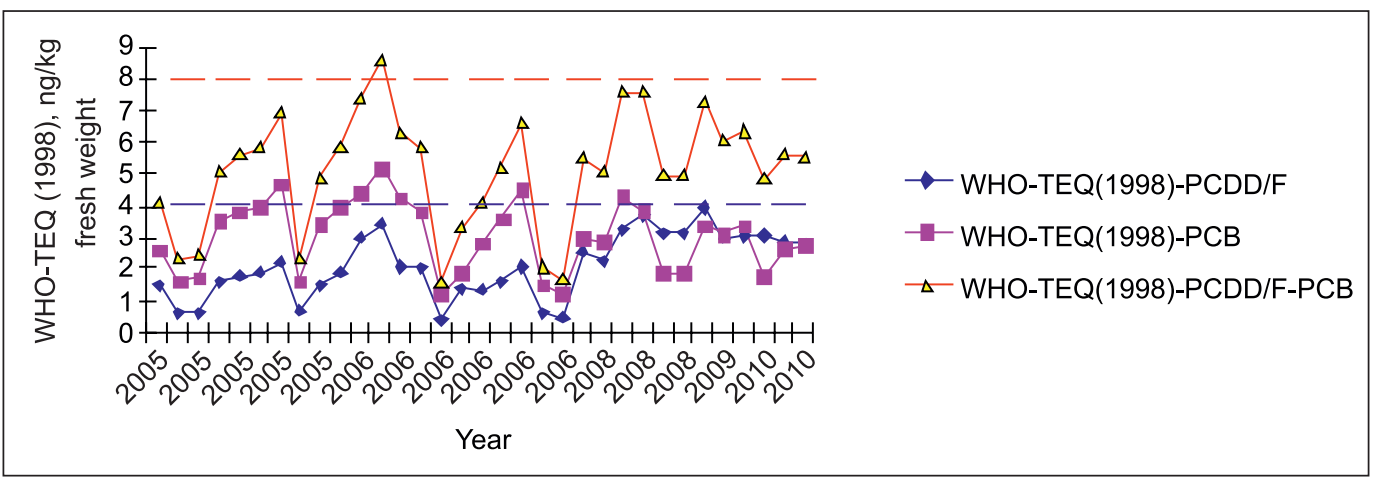

Fig. 9. Baltic sprat analysed in 2005-2010 in Lithuania

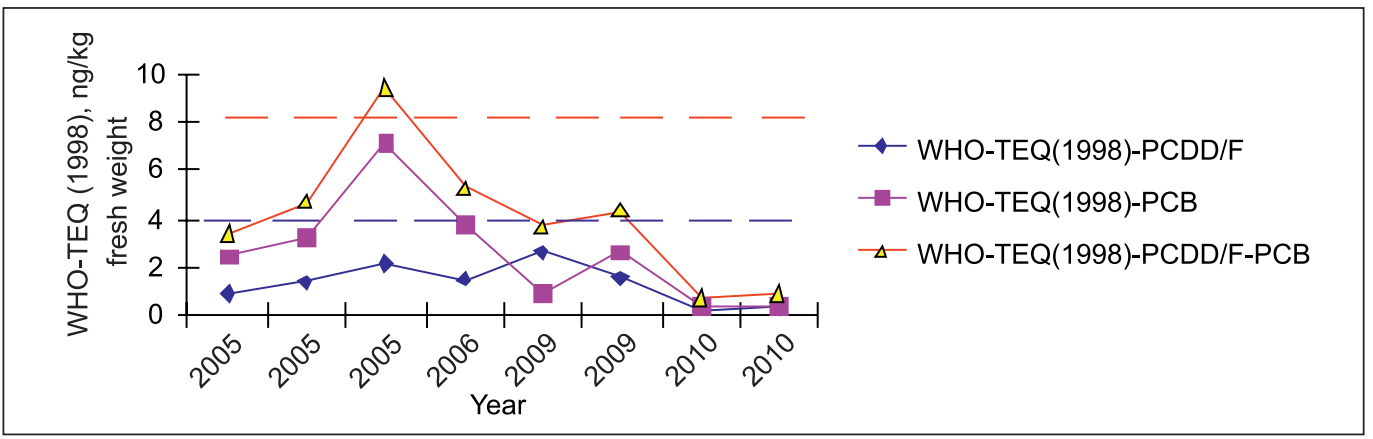

Fig. 10. Baltic salmon analysed in 2005-2010 in Lithuania 


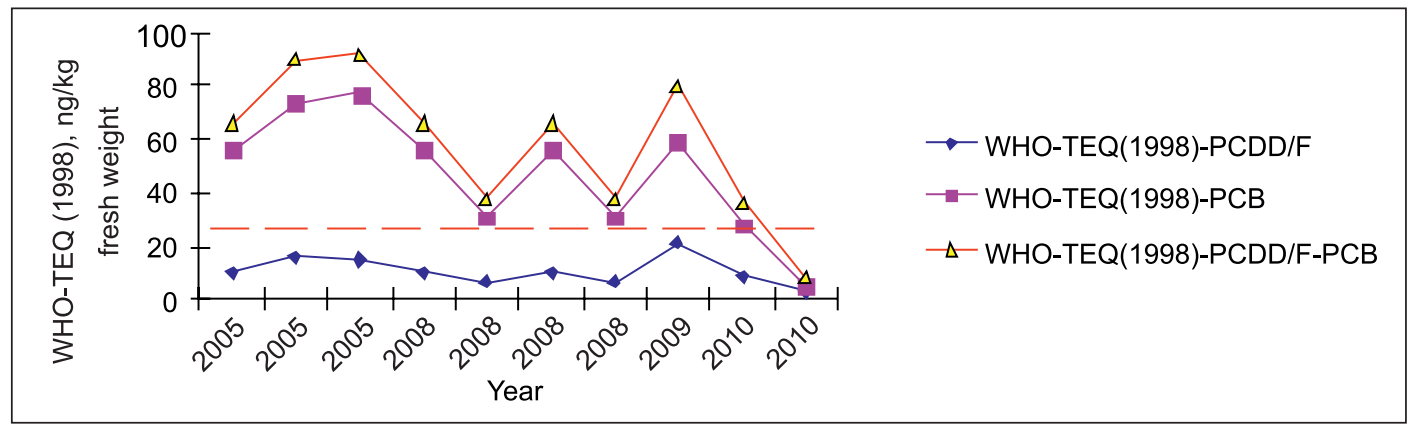

Fig. 11. Baltic cod liver analysed in 2005-2010 in Lithuania

\section{CONCLUSIONS}

Validation data show that these methods can be used as a routine technique in monitoring programmes to determine low dioxin and PCB levels in fish and meat.

Investigation of contamination levels shows that most fish and meat are safe to use in Lithuania. Unfortunately, dioxins and PCB were determined in all samples and their level in some of the samples might have exceeded the maximum limit.

Received 25 May 2011 Accepted 31 August 2011

\section{References}

1. Roots O, Scramm KA, Simm M, Henkelmann B, Lankov A. Polychlorinated dibenzo-p-dioxins and dibenzofurans in Baltic herring and sprats in the north-eastern part of the Baltic Sea. Proc Estonian Acad Sci Biol Ecol 2006; 55(1): 51-60.

2. Food Safety authority of Ireland, Dioxins and PCBs in Food, Toxicology Factsheet Series, Issue No. 1, May 2009.

3. Rappe C, Buser HR, Dodet B, O’Neill IK. Enviromental carcinogens: methods of analysis and exposure measurements. IARC 1991; 11.

4. Method 1613. Tetra trough Okta-Chlorinated Dioxins and Furans by Isotope dilution HRGC / HRMS, 1994 October, U. S. Environmental Protection Agency.

5. Method 1668. Toxic Polychlorinated Byphenyls by Isotope dilution HRGC / HRMS, 1994 October, U. S. Environmental Protection Agency.

6. Commission Regulation (EC) 1883 / 2006 of 19 December 2006 Laying down methods of sampling and analysis for the official control of levels of dioxins and dioxinlike PCBs in certain foodstuffs.

7. Commission Regulation (EC) 1881 / 2006 of 19 December 2006 Setting maximum levels for certain contaminants in foodstuffs.
8. Kiviranta H, Ovaskainen ML, Vartiainen T. Market basket study on dietary intake of PCDD / Fs, PCBs and PBDEs in Finland. Environ Intern 2004; 30: 923-832.

9. Koistinen J, Paasivirta J, Vuorinen PJ. Dioxins and other planar poluchloroaromatic compounds in Baltic, Finnish and Arctic fish samples. Chemosphere 1989; 19(1-6): 230-57.

10. Wiberg K, Sporring S, Haglund P, Bjorklund E. Selective pressurized liquid extraction of polychlorinated dibenzo-p-dioxins, dibenzofurans and dioxin-like polychlorinated biphenyls from food and feed samples. J Chromatogr A 2007; 1138(1-2): 55-64.

11. Reiner EJ, Clement RE, Okey AB, Marvin CH. Advances in analytical techniques for polychlorinated dibenzo-pdioxins, polychlorinated dibenzofurans and dioxin-like PCBs. Anal Bioanal Chem 2006; 386: 791-806.

Rasa Mašaraitė, Julijonas Petraitis, Inga Jarmalaitė, Evaldas Naujalis

\section{DIBENZO-P-DIOKSINŲ, DIBENZOFURANŲ IR DIOKSINŲ PCB TIPO NUSTATYMAS ŽUVYJE IR MÉSOJE LIETUVOJE}

\section{Santrauka}

İdiegti ir įteisinti dibenzo-p-dioksinų, dibenzofuranų ir polichlorintų bifenilų nustatymo metodai žuvies ir mèsos méginiuose. Iteisinti duomenys pagal pasikartojimą ir atkuriamumą atitinka Europos Komisijos reikalavimus. Itteisinti metodai sèkmingai taikomi nustatant PCDD / F ir DT-PCB Baltijos jūros žuvies mėginiuose ir mésoje. PCDD / F ir DT-PCB analizuoti Baltijos silkejje, lašišoje, šprotuose ir menkių kepenyse. Didžiausia leistina koncentracija buvo viršyta 9 iš 25 Baltijos silkès, 2 iš 9 lašišos, 1 iš 33 šprotų ir 9 iš 10 Baltijos menkių kepenų mėginių. Kitų žuvies ir mėsos mėginių koncentracijos atitiko normą.

Raktažodžiai: PCDD, PCDF, DL-PCB, Baltijos jūra, silke, šprotai, iteisinimas 